\title{
Optimasi nilai keausan pahat dan kekasaran permukaan benda kerja terhadap parameter pemesinan milling dengan benda kerja magnesium menggunakan kombinasi metode taguchi dan grey relational analysis
}

\author{
Lucius Patria Giri Dwi Astanto ${ }^{1 *}$, Yanuar Burhanuddin², Gusri Akhyar lbrahim ${ }^{3}$ \\ ${ }^{1}$ Program Magister Teknik Mesin, Fakultas Teknik Universitas Lampung \\ 2 \& 3 Prodi Magister Teknik Mesin, Fakultas Teknik, Universitas Lampung \\ ${ }^{*}$ Corresponding author: Ipg.dwiastanto@bestpower.co.id
}

\begin{abstract}
The Taguchi method is widely used to determine the optimal quality of a process with a single response. While for multi-response cases, Grey Relational Analysis (GRA) and Principal Component Analysis (PCA) are widely used. With multi-phone GRA, it can be simplified into one single response. Tool wear and surface roughness of the workpiece in the milling machining process is affected by the diameter of the tool, depth of feed, spindle speed, and feeding speed. This study examines the response of tool wear and work surface roughness with three levels and four factors. For tool diameters, using $6.8 \mathrm{~mm}$ and $10 \mathrm{~mm}$. The depth of feed used 1; 1,5 mm and $2 \mathrm{~mm}$. Spindle speeds at 910, 1280, and $1700 \mathrm{rpm}$. While the feeding speed is $75 \mathrm{~mm} /$ minute, $145 \mathrm{~mm} /$ minute, and $220 \mathrm{~mm} /$ minute. Optimal results obtained in conditions of $6 \mathrm{~mm}$ tool diameter with 1,5 mm depth of feeding, spindle speed of $1280 \mathrm{rpm}$, and feeding speed of $75 \mathrm{~mm} /$ minute. The optimal response obtained is $0,059 \mathrm{~mm}$ for tool wear and $0,364 \mu \mathrm{m}$ for work surface roughness. The significant factor influencing is the feeding speed which influences $76,14 \%$.
\end{abstract}

Keywords: Grey Relational Analysis, Principal Component Analysis, Taguchi Method, Milling, Tool Wear, Roughness

\begin{abstract}
Abstrak
Metode Taguchi banyak dipakai untuk menentukan kualitas optimal suatu proses dengan single respon. Sedangkan untuk kasus multirespon banyak dipakai Grey Relational Analysis (GRA) yang dibantu dengan Principal Component Analysis (PCA). Dengan GRA multirepon dapat disederhanakan menjadi satu respon tunggal. Keausan pahat dan kekasaran permukaan benda kerja pada proses pemesinan milling dipengaruhi faktor diameter pahat, kedalaman pemakanan, kecepatan spindle maupun kecepatan makan. Penelitian ini meneliti respon keausan pahat dan kekasaran permukaan benda kerja dengan tiga level dan empat faktor. Untuk diameter pahat dipakai pahat 6,8 dan $10 \mathrm{~mm}$. Kedalaman makan yang dipakai 1; 1,5 dan $2 \mathrm{~mm}$. Kecepatan spindle pada 910,1280 dan $1700 \mathrm{rpm}$. Sedangkan kecepatan pemakanan pada 75,145 , dan $220 \mathrm{~mm} /$ menit. Hasil optimal yang didapat pada kondisi diameter pahat $6 \mathrm{~mm}$, kedalaman makan 1,5 mm, kecepatan spindle $1280 \mathrm{rpm}$ serta kecepatan pemakanan $75 \mathrm{~mm} / \mathrm{menit}$. Respon optimal yang didapatkan adalah keausan pahat $0,059 \mathrm{~mm}$ serta kekasaran permukaan benda kerja $0,364 \mu \mathrm{m}$. Faktor yang signifikan berpengaruh adalah kecepatan pemakanan berpengaruh sebesar 76,14\%.

Kata kunci: Grey Relational Analysis, Principal Component Analysis, Taguchi Method, Milling, Keausan Pahat, Kekasaran Permukaan
\end{abstract}

\section{Pendahuluan}

Proses manufaktur adalah suatu cara atau proses yang diterapkan untuk merubah bentuk suatu benda. Tujuan proses manufaktur adalah untuk menghasilkan komponen-komponen yang menggunakan 
material mempertimbangkan bentuk, ukuran dan strukturnya. Proses ini sangat berhubungan erat dengan dunia pemesinan. Industri yang terkait manufaktur yang didukung oleh proses pemesinan menjadi andalan bagi pertumbuhan industri non migas di Indonesia. Material benda kerja yang akan dibentuk dalam proses pemesinan juga berpengaruh terhadap keandalan pahat / alat potong. Material yang sedang mengalami perkembangan pesat dalam dunia Industri adalah Magnesium. Menurut Zgorniak dan Grdulska [1] dalam beberapa kasus pemesinan, komponen-komponen benda kerja dibuat dari paduan Magnesium untuk mengurangi bobot dan memastikan sifat mekanik dari sifat tahan panasnya. Fakta bahwa Magnesium Alloy adalah paduan teringan menjadikannya pilihan utama untuk digunakan di beberapa industri, seperti di otomotif dan kedirgantaraan. Industri otomotif mulai memakai Magnesium Alloy di tahum 1930an. Contoh penggunaannya oleh produsen mobil Volkswagen atau helikopter Sikorsky di tahun 1950-an dan meluas sampai hari ini, dengan paduan Magnesium yang digunakan dalam aplikasi teknologi tinggi seperti di Formula 1 dan pesawat Boeing [2]. Magnesium Alloys digunakan sebagai bahan pembuat pesawat seperti Sikorsky S-56, the Lockheed F-80C the Convair B-36 Peacemaker dan the Tupolev TU-95MS.

Meskipun material paduan magnesium memiliki beberapa kelebihan dalam sifat kimia dan fisikanya, namun dalam proses pemesinan paduan Magnesium dikenal sebagai material jenis logam yang mudah terbakar, terutama pada saat proses pemesinan dengan kecepatan tinggi [3]. Saat proses pemesinan berlangsung, terjadi gesekan antara benda kerja dan pahat potong yang dapat menimbulkan panas. Suhu yang ditimbulkan sampai titik nyala sehingga menimbulkan api. Demikian juga gesekan antara geram dan permukaan atas pahat menimbulkan panas yang tinggi. Bahkan panas yang dihasilkan dapat menyebabkan geram terbakar [4].

Proses pemesinan dipengaruhi banyak faktor terkait keandalannya. Keausan pahat / alat potong dan panas yang dialami pahat merupakan faktor yang berpengaruh pada keandalan / umur pahat [5]. Keausan pahat juga mempengaruhi kualitas hasil pemesinan. Ersvik, et. al [6] melakukan penelitian tentang tool wear pada mesin milling konvensional dibandingkan dengan mesin miling dinamik. Hasil penelitian menunjukkan laju keausan optimum didapat pada mesin milling dinamik. Kaining, et.al [7] melakukan penelitian keausan pada pahat carbide pada mesin milling dengan benda kerja AZ91D Magnesium Alloy. Keausan yang dominan terjadi adalah flaking, depth of cut nose wear dan abrasi. Secara khusus, extensive flaking signifikan terjadi pada kecepatan pemotongan $1600 \mathrm{~m} /$ menit, sedangkan serious flank wear dan gross fracture terjadi pada kecepatan pemotongan 1800 dan 2000 $\mathrm{m} / \mathrm{menit}$.

Dominic [8] melakukan penelitian pada mesin milling untuk memprediksi tool wear dengan memakai pahat 2 flute uncoated sintered tungsten carbide in cobalt binder. Benda kerja yang dimodelkan adalah Aluminum 6061-T6 dan commercially pure (CP) Titanium. Hasil yang diperoleh adalah flank wear dan nose wear ditemukan pada pengujian dengan benda kerja Alumunium dan meningkat seiring dengan kecepatan makan tool. Sedang nose wear secara signifikan ditemukan saat pengujian dengan benda kerja Titanium.

Kekasaran permukaan benda kerja setelah pemesinan juga menjadi faktor yang diperhatikan. Kecepatan pemotongan, kedalaman pemotongan maupun kecepatan makan mempengaruhi hasil kekasaran permukaan benda kerja. Muralidharan, et. al [9] melakukan pengujian pada mesin milling untuk mengetahui pengaruh jenis pelapis pahat, kecepatan potong, kecepatan makan dan kedalaman makan terhadap kekasaran permukaan. Benda kerja yang digunakan adalah Magnesium Composite. Hasil optimum didapat pada kecepatan makan $2000 \mathrm{~mm} /$ menit, kecepatan putar $2500 \mathrm{rpm}$ dan akan bertambah kekasarannya seiring bertambahnya kedalaman potong. Gopal, et. al [10] melakukan pengujian pada mesin 
milling dengan benda kerja Magnesium Composite untuk mengetahui pengaruh dari, kecepatan putar, kecepatan makan dan kedalaman makan terhadap kekasaran permukaan. Hasilnya kekasaran optimum didapat pada kecepatan putar $710 \mathrm{rpm}$, kecepatan makan $20 \mathrm{~mm} / \mathrm{menit}$ dan kedalaman makan 0,5 mm.

Penelitian terhadap mesin milling untuk mengetahui keausan pahat maupun kekasaran permukaan memerlukan banyak pengujian. Semakin banyak jumlah pengujian semakin lama waktu penelitian maupun biaya penelitian. Cara untuk mengurangi jumlah eksperimen adalah dengan memakai desain eksperimen dengan metode Taguchi. Metode ini dikembangkan oleh Dr. Genichi Taguchi. Metode ini dibagi dalam tiga tingkat yaitu desain sistem, desain parameter dan desain toleransi. Metode Taguchi merupakan metode statistik yang dipakai untuk meningkatkan kualitas produk. Proses Taguchi membantu menentukan kondisi pemotongan yang optimum untuk suatu proses. Taguchi mengembangkan suatu desain khusus berupa orthogonal arrays untuk mempelajari seluruh bidang parameter dengan hanya menggunakan sedikit percobaan. Hasil percobaan - percobaan tersebut kemudian ditransformasikan kedalam suatu rasio signalto-noise ( $\mathrm{S} / \mathrm{N}$ ). Penggunaan rasio $\mathrm{S} / \mathrm{N}$ sebagai suatu pengukur penyimpangan sifat-sifat kualitas atau dari nilai-nilai yang mendekati ke nilai yang diinginkan. Ada tiga kategori dari sifat-sifat kualitas dalam analisa dari rasio $\mathrm{S} / \mathrm{N}$ yaitu lebih rendah lebih baik, lebih tinggi lebih baik dan nominal lebih baik [11]. Metode Taguchi digunakan untuk mendapatkan kondisi optimum untuk satu respon. Sedang untuk mengetahui kondisi optimum pada beberapa respon, metode Taguchi dapat dikombinasikan dengan pendekatan Grey Relational Analysis (GRA) dan Principal Component Analysis (PCA). Dengan kombinasi tersebut diharapkan kesimpulan yang didapat dapat lebih efisien untuk menentukan kondisi optimum dari beberapa parameter. Melalui GRA penelitian dengan jumlah sampel sedikit dan informasi yang terbatas dapat dianalisis untuk memperoleh kondisi optimum. Sedang PCA dipakai untuk mengetahui korelasi antar respon dan menentukan nilai pembobot sehingga kombinasi antar level faktor dapat optimal. Gopal, et. al [10] memakai gabungan Taguchi, GRA dan PCA untuk mengetahui kondisi optimum dari proses milling dengan benda kerja Magnesium Composite. Hasil dari gabungan metode tersebut menghasilkan rekomendasi kekasaran optimum pada $0.198 \mu \mathrm{m}$ untuk kombinasi parameter pemesinan pada gaya makan $139,48 \mathrm{~N}$, temperatur $68,96^{\circ} \mathrm{C}$. Penelitian lain yang membahas keausan pahat maupun kekasaran permukaan pada milling menggunakan gabungan Metode Taguchi, GRA dan PCA dilakukan oleh Taminoli, et. al [12] yang melakukan penelitian untuk mengetahui kekasaran optimum pada benda uji Aluminum Alloy $6082 \mathrm{~T} 6$ pada mesin milling menggunakan kombinasi metode Taguchi dan Grey Relational Analysis. Aslantas, et. al [13] telah meneliti multi respon optimum, yaitu burr dan kekasaran permukaan Ti6Al-4V alloy dari proses milling dengan kombinasi metode Taguchi dan Grey Relational Analysis.

Dari uraian di atas dapat diperoleh informasi bahwa sudah banyak penelitian yang mengamati korelasi respon permesinan dengan faktor atau parameter permesinan. Tetapi penelitian-penelitian tersebut masih mengamati kondisi optimum untuk respon tunggal. Oleh karena itu, penelitian yang akan dilakukan penulis adalah bertujuan untuk mendapatkan kondisi proses pemesinan dry end milling yang optimal terhadap material paduan Magnesium AZ31 dengan respon yang diamati adalah keausan alat potong dan kekasaran permukaan benda kerja. Parameter yang diamati adalah diameter pahat, kecepatan putar, kecepatan makan dan kedalaman makan. Metode yang dipakai adalah gabungan dari Metode Taguchi, GRA dan PCA. Dengan kata lain, empat faktor pemesinan yang diteliti akan dicari kondisi optimumnya untuk mendapatkan keausan alat potong yang minimal sekaligus mendapatkan kekasaran permukaan benda kerja yang minimal pula. 


\section{Metode Penelitian}

Penelitian direncanakan memakai mesin milling milko 12 seperti tampak pada Gambar 1. Sedangkan pahat potong yang dipakai berdiameter 6,8 dan $10 \mathrm{~mm}$, merek YG-1 dengan jenis HSS 2 flute seperti pada Gambar 2. Bahan benda kerja yang dipakai adalah Magnesium AZ 31 seperti pada Gambar 3. Direncanakan akan ada empat faktor percobaan dengan tiga level dan memakai orthogonal array L9, tampak pada Tabel 1. Respon percobaaan yang diamati adalah keausan pahat sisi dan kekasaran benda kerja.
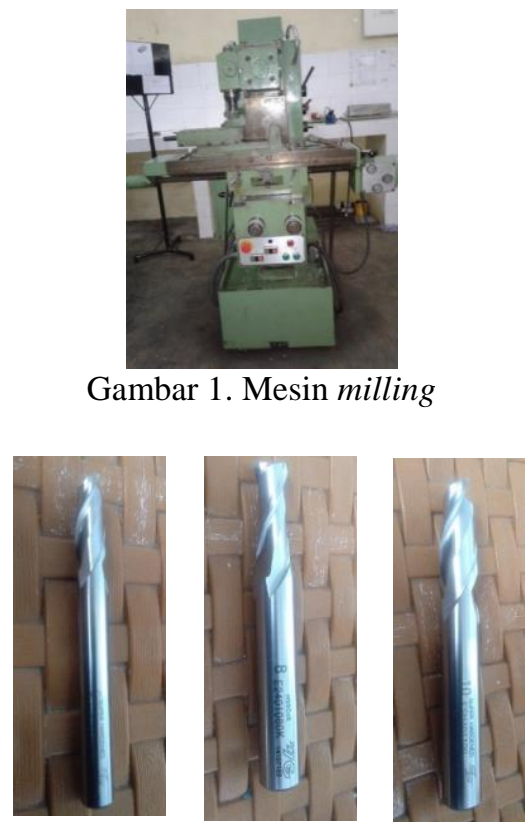

Gambar 2. Pahat HSS, 2 flute
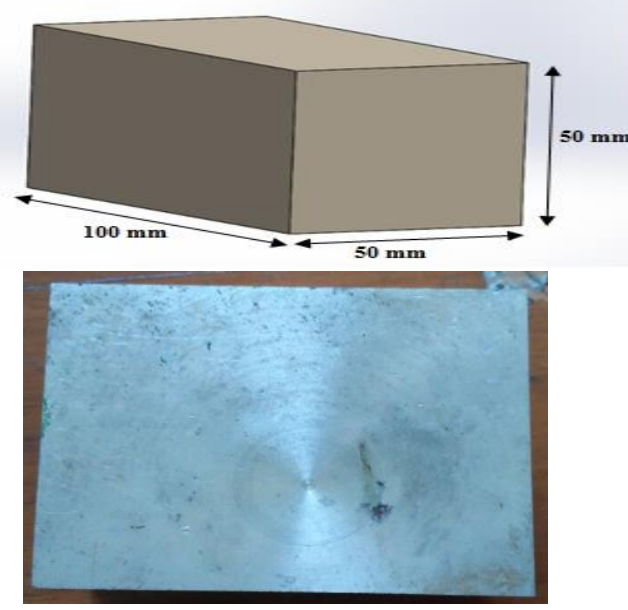

Gambar 3. Benda kerja
Tabel 1. Orthogonal array L9

\begin{tabular}{ccccc}
\hline $\begin{array}{c}\text { Run } \\
\text { Order }\end{array}$ & $\begin{array}{c}\mathrm{A} \\
\text { Dia. } \\
\text { Pah } \\
\text { at } \\
\text { (m }\end{array}$ & $\begin{array}{c}\text { Bedala } \\
\text { man } \\
\text { Makan } \\
\text { (mm) }\end{array}$ & $\begin{array}{c}\text { C } \\
\text { Kecepat } \\
\text { an } \\
\text { Spindle } \\
\text { (RPM) }\end{array}$ & $\begin{array}{c}\text { Decepata } \\
\text { n Makan } \\
\text { (mm/me } \\
\text { nit) }\end{array}$ \\
\hline 1 & 6 & 1 & 910 & 75 \\
\hline 2 & 6 & 1,5 & 1280 & 145 \\
\hline 3 & 6 & 2 & 1700 & 220 \\
\hline 4 & 8 & 1 & 1280 & 220 \\
\hline 5 & 8 & 1,5 & 1700 & 75 \\
\hline 6 & 8 & 2 & 910 & 145 \\
\hline 7 & 10 & 1 & 1700 & 145 \\
\hline 8 & 10 & 1,5 & 910 & 220 \\
\hline 9 & 10 & 2 & 1280 & 75 \\
\hline & & & &
\end{tabular}

Tahapan dari pengolahan data direncanakan dengan terlebih dahulu melakukan Taguchi analysis untuk mencari kombinasi optimal dari semua faktor untuk setiap respon, dengan mencari Signal Noise Ratio (SNR). SNR untuk ketiga respon tersebut sama yaitu Smaller-the-Better (STB). Rumus yang diapakai adalah :

1. Menghitung SN Ratio sesuai dengan metode Taguchi :

SNR STB $=-10 \log \left[X i(j)^{2}\right]$

Dengan:

$X i(j)=$ nilai eksperimen ke $-i$ pada respon ke- $\mathrm{j}$

2. Melakukan normalisasi SN Ratio.

Besar nilai normalisasi SNR antara 0 sampai 1. Persamaan yang dipakai untuk normalisasi adalah :

$X i^{*}(j)=\frac{X i(j)-\min X i(j)}{\operatorname{maks} X i(j)-\min X i(j)}$

Dengan:

$X i^{*}(j)=$ nilai normalisasi SNR pada percobaan ke- i dan respon ke-j

$X i(j)=$ nilai eksperimen ke $-\mathrm{i}$ pada respon ke-j

$\mathrm{i}=$ banyaknya percobaan

$\mathrm{j}=$ banyaknya respon

3. Menghitung nilai delta

Menghitung jarak $\Delta o i(j)$ yang merupakan nilai absolut dari selisih antara nilai maksimum hasil normalisasi $X o^{*}(j)$ dengan data yang telah dinormalisasi $X i^{*}(j)$ pada titik j. Persamaan yang digunakan adalah sebagai berikut: 
$\Delta o i(j)=\left|X o^{*}(j)-X i^{*}(j)\right|$

Dengan:

$X o^{*}(j)=1$ (nilai terbesar normalisasi

S/N Ratio diinversikan sebesar 1)

4. Menghitung nilai gamma (Grey Relational Coefficient / GRC). GRC menunjukkan hubungan antara kondisi terbaik dengan kondisi aktual dari respon yang dinormalisasi. Persamaan yang digunakan untuk mendapatkan nilai GRC adalah sebagai berikut :

$\gamma_{o i}=\frac{\Delta m i n+\zeta \Delta m a k s}{\Delta o i(j)+\zeta \Delta m a k s}$

Dengan:

$\Delta \min =$ nilai minimum dari $\Delta o i(j)$

$\Delta m a k s=$ nilai maksimum dari $\Delta o i(j)$ $\zeta=$ koefisisien pembeda, biasanya diambil nilai 0,5

5. Menghitung Grey Relational Grade

Rumus yang dipakai adalah:

$\Gamma_{o i(j)}=\sum_{j=1}^{n} \beta_{j} \gamma_{o i}(j)$

Dengan:

$\beta_{j}$ menggambarkan nilai bobot ke-j dari karakteristik respon dan nilai bobot diperoleh dari nilai vektor eigen komponen utama terpilih yang dikuadratkan. Misalkan komponen utama yang terpilih adalah komponen utama 1.

$\beta_{j}=a_{i j}^{2} \quad, \quad$ dengan $\quad a_{11}^{2}+$ $a_{12}{ }^{2} \ldots \ldots+a_{i k}{ }^{2}=1$

Sedangkan:

a11 : nilai pertama dari vektor eigen 1 a12 : nilai kedua dari vektor eigen 1 a1k : nilai ke-k dari vektor eigen 1

6. Menghitung nilai prediksi

Nilai GRG kombinasi faktor yang tidak ada dalam kombinasi run order metode Taguchi dapat diprediksi dengan rumus:

$\hat{\gamma}=\gamma_{m}+\sum_{i=1}^{k}\left(\bar{\gamma}_{l}-\gamma_{m}\right)$

Dengan:

$\hat{\gamma}=$ Nilai prediksi GRG

$\gamma_{m}=$ Nilai total rata-rata GRG

$\overline{\gamma_{l}}=$ Nilai rata-rata GRG pada tiap optimal level $k=$ jumlah parameter atau faktor yang berpengaruh.

7. Selanjutnya dilakukan ANOVA terhadap Grey Relational Grade untuk mengetahui faktor mana yang berpengaruh signifikan terhadap respon GRG.

\section{Hasil dan Pembahasan}

Dari hasil pengujian didapatkan data seperti dalam Tabel 2. Percobaan dilakukan dengan melakukan dua replikasi untuk setiap respon. Berikutnya akan dilakukan pengolahan data untuk memperoleh nilai respon optimal dari gabungan keempat faktor percobaan tersebut.

Tabel 2. Data hasil pengujian

\begin{tabular}{|c|c|c|c|c|c|c|}
\hline \multirow{2}{*}{$\begin{array}{c}\text { Run } \\
\text { Or } \\
\text { der }\end{array}$} & \multicolumn{3}{|c|}{ Keausan (mm) } & \multicolumn{3}{|c|}{ Kekasaran / Ra $(\mu m)$} \\
\hline & $\begin{array}{c}\text { Replik } \\
\text { asi } 11 \\
\end{array}$ & $\begin{array}{c}\text { Replik } \\
\text { asi } 2 \\
\end{array}$ & $\begin{array}{c}\text { Rata- } \\
\text { rata }\end{array}$ & $\begin{array}{c}\text { Replik } \\
\text { asi } 1 \\
\end{array}$ & $\begin{array}{c}\text { Replik } \\
\text { asi } 2 \\
\end{array}$ & $\begin{array}{l}\text { Rata- } \\
\text { rata }\end{array}$ \\
\hline 1 & 0.063 & 0.051 & $\begin{array}{l}0.05 \\
7 \\
\end{array}$ & 0,498 & 0,538 & $\begin{array}{l}0,51 \\
8 \\
\end{array}$ \\
\hline 2 & 0.06 & 0.063 & $\begin{array}{l}0.06 \\
2 \\
\end{array}$ & 0,500 & 0,540 & $\begin{array}{l}0,52 \\
0 \\
\end{array}$ \\
\hline 3 & 0.234 & 0.241 & $\begin{array}{l}0.23 \\
8 \\
\end{array}$ & 0,652 & 0,692 & $\begin{array}{l}0,67 \\
2\end{array}$ \\
\hline 4 & 0.34 & 0.446 & $\begin{array}{l}0.31 \\
1 \\
\end{array}$ & 0,661 & 0,701 & $\begin{array}{l}0,68 \\
1 \\
\end{array}$ \\
\hline 5 & 0.148 & 0.103 & $\begin{array}{l}.12 \\
6 \\
\end{array}$ & 0,374 & 0,414 & $\begin{array}{l}0,39 \\
4 \\
\end{array}$ \\
\hline 6 & 0.178 & 0.103 & $\begin{array}{l}0.14 \\
1 \\
\end{array}$ & 0,561 & 0,601 & $\begin{array}{l}0,58 \\
1 \\
\end{array}$ \\
\hline 7 & 0.277 & 0.247 & $\begin{array}{l}0.26 \\
2 \\
\end{array}$ & 0,442 & 0,482 & $\begin{array}{l}0,46 \\
2\end{array}$ \\
\hline 8 & 0.168 & 0.162 & $\begin{array}{l}0.16 \\
5 \\
\end{array}$ & 0,778 & 0,818 & $\begin{array}{l}0,79 \\
8 \\
\end{array}$ \\
\hline 9 & 0.104 & 0.09 & $\begin{array}{l}0.09 \\
7\end{array}$ & 0,453 & 0,493 & $\begin{array}{l}0,47 \\
3\end{array}$ \\
\hline
\end{tabular}

Setelah data percobaan diperoleh, selanjutnya dicari SN Ratio untuk masingmasing respon. Respon dari percobaan ini adalah keausan dan kekasaran. Karakteristik kedua respon itu adalah smaller is better yang dapat dihitung dengan persamaan (1). Hasil perhitungan dapat dilihat pada Tabel 3.

Tabel 3. SNR setiap respon

\begin{tabular}{ccc}
\hline Run Order & $\begin{array}{l}\text { SNR (small } \\
\text { is better) } \\
\text { Keausan }\end{array}$ & $\begin{array}{l}\text { SNR (small is } \\
\text { better) } \\
\text { Kekasaran }\end{array}$ \\
\hline 1 & 24,883 & 5,713 \\
\hline 2 & 24,222 & 5,680 \\
\hline 3 & 12,487 & 3,453 \\
\hline 4 & 10,145 & 3,337 \\
\hline 5 & 18,027 & 8,090 \\
\hline
\end{tabular}




\begin{tabular}{ccc}
\hline Run Order & $\begin{array}{l}\text { SNR (small } \\
\text { is better) } \\
\text { Keausan }\end{array}$ & $\begin{array}{l}\text { SNR (small is } \\
\text { better) } \\
\text { Kekasaran }\end{array}$ \\
\hline 6 & 17,046 & 4,716 \\
\hline 7 & 11,634 & 6,707 \\
\hline 8 & 15,650 & 1,960 \\
\hline 9 & 20,265 & 6,503 \\
\hline
\end{tabular}

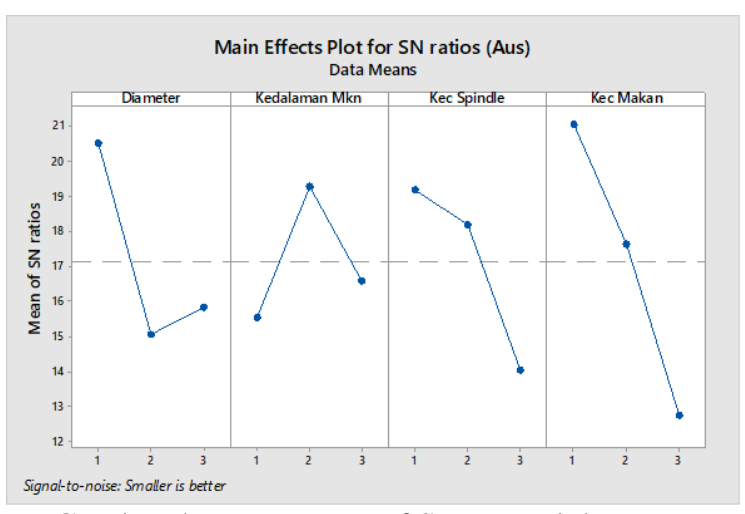

Gambar 4. Data means of SNR untuk keausan

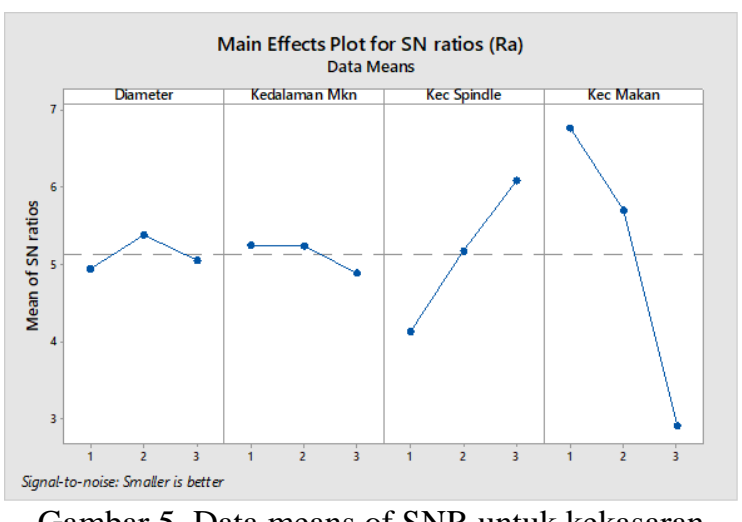

Gambar 5. Data means of SNR untuk kekasaran

Dari perhitungan terhadap tiga respon tersebut diperoleh nilai optimal untuk masing-masing respon seperti pada Tabel Faktor optimal masing-masing respon (4).

Tabel 4. Faktor optimal masing-masing respon

\begin{tabular}{lcccc}
\hline Respon & \multicolumn{4}{c}{ Faktor optimal } \\
\hline Keausan & A2 & B1 & C3 & D3 \\
\hline Kekasaran & A1 & B3 & C1 & D3 \\
\hline
\end{tabular}

Dari Tabel 4 dapat diketahui bahwa untuk kedua respon percobaan didapatkan faktor yang optimal berbeda-beda kombinasinya. Kombinasi faktor optimal untuk keausan adalah diameter pahat $8 \mathrm{~mm}$, kedalaman potong $1 \mathrm{~mm}$, kecepatan spindle 1700 rpm dan kecepatan makan 220 $\mathrm{mm} / \mathrm{menit}$. Sedang kombinasi faktor optimal untuk kekasaran permukaan adalah diameter pahat $1 \mathrm{~mm}$, kedalaman potong 2 $\mathrm{mm}$, kecepatan spindle $910 \mathrm{rpm}$ dan kecepatan makan $220 \mathrm{~mm} /$ menit.

Selanjutnya akan dilakukan Anova dua arah untuk mengetahui signifikansi tiap faktor terhadap respon. Dengan memakai software minitab dapat diketahui hasil ANOVA tiap respon, seperti tampak pada Tabel 5 dan Tabel 6.

Tabel 5. Hasil ANOVA kontribusi tiap faktor terhadap keausan pahat

\begin{tabular}{cccc}
\hline Faktor & Adj SS & F-Value & $\begin{array}{c}\text { Persen } \\
\text { Kontribusi }\end{array}$ \\
& & & \\
\hline A & 0,01775 & 12,94 & \\
& & & $13,02 \%$ \\
\hline B & 0,025875 & 18,86 & $18,98 \%$ \\
\hline C & 0,02323 & 16,93 & $17,04 \%$ \\
\hline D & 0,063255 & 46,10 & $46,41 \%$ \\
\hline ERR & 0,006174 & & $4,53 \%$ \\
\hline TOTA L & 0,136284 & & $100,00 \%$ \\
\hline
\end{tabular}

Tabel 6. Hasil ANOVA kontribusi tiap faktor terhadap kekasaran permukaan

\begin{tabular}{lrrr}
\hline Faktor & Adj SS & $\begin{array}{c}\text { F- } \\
\text { Value }\end{array}$ & $\begin{array}{c}\text { Persen } \\
\text { kontribusi }\end{array}$ \\
\hline $\mathrm{A}$ & 0,002083 & 1,30 & $0,768 \%$ \\
\hline $\mathrm{B}$ & 0,00156 & 0,98 & $0,575 \%$ \\
\hline $\mathrm{C}$ & 0,046046 & 28,78 & $16,982 \%$ \\
\hline $\mathrm{D}$ & 0,214263 & 133,91 & $79,020 \%$ \\
\hline ERR & 0,0072 & & $2,655 \%$ \\
\hline TOTAL & 0,271152 & & $100,000 \%$ \\
\hline
\end{tabular}

Untuk respon keausan, dengan $\mathrm{F}$ tabel $=\mathrm{F}(0,05 ; 3 ; 9)=3,86$, didapati bahwa semua faktor signifikan berpengaruh (semua $F_{\text {hitung }}>$ 3,86). Dengan urutan paling berpengaruh adalah faktor kecepatan makan memiliki kontribusi 46,41\%, faktor kedalaman makan memiliki kontribusi $18,98 \%$, faktor kecepatan spindle berkontribusi $17,04 \%$ dan faktor diameter pahat berkontribusi $13,02 \%$. Semua faktor memang signifikan berpengaruh tetapi kontribusi terbesar (hampir mencapai $50 \%$ ) dimiliki oleh faktor kecepatan makan. Karena faktor optimal yang paling besar kontribusinya adalah faktor kecepatan makan, akan dilihat lebih lanjut apakah 
faktor ini juga signifikan terhadap respon kekasaran permukaan.

Untuk kekasaran permukaan, faktor kecepatan makan $\left(F_{\text {hitung }}=133,91>3,86\right)$ dan faktor kecepatan spindle $\left(\mathrm{F}_{\text {hitung }}=28,78\right.$ $>3,86$ ) mempunyai pengaruh signifikan. Berdasarkan Tabel. 18, didapatkan data bahwa kecepatan pemakanan yang optimal adalah D3 atau $220 \mathrm{~mm} \mathrm{/} \mathrm{menit}$ (berpengaruh 79,02 \%) serta kecepatan spindle optimal adalah $\mathrm{C} 1$ atau $910 \mathrm{rpm}$ (berpengaruh 16,98\%). Jadi, kecepatan pemakanan tertinggi digabung dengan kecepatan spindle terendah akan menghasilkan kekasaran yang optimal.

Hasil lengkap dari optimasi SNR dan ANOVA dapat dilihat pada Tabel 7.

Tabel 7. Hasil optimasi SNR dan ANNOVA

\begin{tabular}{|c|c|c|}
\hline \multirow[b]{2}{*}{ Respon } & \multicolumn{2}{|c|}{ Metode Taguchi } \\
\hline & $\begin{array}{c}\text { Kombinasi } \\
\text { Faktor } \\
\text { Optimal }\end{array}$ & $\begin{array}{c}\text { Faktor } \\
\text { Signifikan }\end{array}$ \\
\hline $\begin{array}{l}\text { Keausan } \\
\text { pahat }\end{array}$ & A2 B1 C3 D3 & $\begin{array}{l}\text { Kecepatan } \\
\text { makan }(46,41 \%) \\
\text { Kedalaman } \\
\text { makan }(18,98 \%) \\
\text { Kecepatan } \\
\text { spindle } \\
(17,04 \%) \\
\text { Diameter pahat } \\
(13,02 \%)\end{array}$ \\
\hline $\begin{array}{l}\text { Kekasaran } \\
\text { permukaan } \\
\text { benda } \\
\text { kerja }\end{array}$ & A1 B3 C1 D3 & $\begin{array}{l}\text { Kecepatan } \\
\text { makan }(79,02 \\
\%) \\
\text { Kecepatan } \\
\text { spindle }(16,98 \\
\%) \\
\end{array}$ \\
\hline
\end{tabular}

Pada faktor diameter pahat, untuk respon keausan pahat maupun kekasaran permukaan, diameter pahat yang optimal tidak berada di diameter terbesar. Hal ini dapat disebabkan karena pahat yang dipakai adalah 2 flute, sehingga ruang tanpa singgungan pahat ke benda kerja lebih besar yang menyebabkan pembersihan chip lebih cepat. Hal ini akan menyebabkan gesekan berkurang sehingga menghasilkan laju keausan pahat yang kecil. Pada respon kekasaran permukaan, persen kontribusi untuk diameter pahat sangat kecil, sebesar
$0,76 \%$. Hal ini berarti besaran level diameter pahat tidak terlalu berkontribusi pada respon kekasaran permukaan.

Pada faktor kedalaman makan, untuk respon keausan pahat didapatkan kedalaman makan di level terendah. Hal ini dapat dimungkinkan karena waktu gesekan pahat dengan benda kerja yang singkat (karena belum terlalu dalam) sehingga laju keausan pahat juga kecil. Ditambah lagi digabung dengan faktor kecepatan spindle dan kecepatan makan yang maksimum (di level tertinggi). Sedangkan untuk respon kekasaran permukaan, faktor kedalaman makan yang optimal berada di level tertinggi. Hal ini dapat disebabkan, walaupun waktu gesek yang terjadi lama, tetapi karena kombinasi faktor diameter pahat yang terkecil dengan kecepatan makan yang terbesar maka bidang gesekan pahat dengan benda kerja akan berlangsung singkat sehingga kekasaran permukaan benda kerja akan kecil. Penggunaan pahat end mill 2 flute dapat menghasilkan keausan yang rendah untuk pengerjaaan cepat, karena bidang dan waktu kontak yang singkat.

Pada faktor kecepatan spindle, untuk respon keausan, didapatkan level kecepatan spindle tertinggi. Hal ini dapat dijelaskan bahwa dengan putaran spindle yang tinggi kontak antara pahat dengan benda kerja terjadi secara cepat, ditambah lagi pahat yang dipakai berjenis 2 flute, sehingga panas yang dapat menyebabkan keausan juga dapat dihindari. Sedangkan untuk respon kekasaran, ternyata didapatkan faktor kecepatan spindle optimal di level terendah. Hal ini perlu dicek lebih lanjut apakah faktor ini berpengaruh signifikan dan berapa persen kontribusinya terhadap kekasaran permukaan. Jika hanya melihat satu faktor saja, yaitu kecepatan spindle, maka seharusnya dengan kecepatan spindle tinggi akan menghasilkan kekasaran permukaan yang rendah. Dari hasil ANOVA diketahui kecepatan spindle rendah tersebut hanya memberikan persen kontribusi terhadap kekasaran permukaan sebesar 16,98\%. Artinya ada faktor lain (dalam hal ini kecepatan makan 
dengan persen kontribusi 79,02\%) yang lebih berpengaruh terhadap kekasaran permukaan

Pada faktor kecepatan makan, untuk respon pada keausan maupun pada kekasaran permukaan, didapatkan hasil di level yang sama, yaitu level tertinggi. Dengan kecepatan pemakanan tinggi menyebabkan waktu kontak pahat dengan benda kerja juga berlangsung cepat sehingga meminimalkan laju keausan pahat dan keausan permukaan benda kerja.

Faktor kecepatan menjadi satusatunya faktor signifikan yang muncul untuk respon keausan dan kekasaran permukaan. Hal ini akan dicek lebih lanjut dengan Metode Grey Relational Analysis untuk mengetahui apakah memang faktor kecepatan makan ini akan menjadi faktor yang signifikan untuk multirespon.

Langkah awal dari GRA adalah perhitungan normalisasi SNR yang dapat dilihat pada Tabel 8, sedangkan perhitungan nilai delta dan GRC terdapat pada Tabel 9.

Tabel 8. Normalisasi SNR

\begin{tabular}{ccc}
\hline Run order & \multicolumn{2}{c}{ Nomalisasi SNR } \\
\cline { 2 - 3 } & Keausan & Kekasaran \\
\hline 1 & 1,000 & 0,612 \\
\hline 2 & 0,955 & 0,607 \\
\hline 3 & 0,159 & 0,243 \\
\hline 4 & 0,000 & 0,225 \\
\hline 5 & 0,535 & 1,000 \\
\hline 6 & 0,468 & 0,450 \\
\hline 7 & 0,101 & 0,774 \\
\hline 8 & 0,374 & 0,000 \\
\hline 9 & 0,687 & 0,741 \\
\hline
\end{tabular}

Tabel 9. Delta dan GRC

\begin{tabular}{ccccc}
\hline \multirow{2}{*}{$\begin{array}{c}\text { Run } \\
\text { orde } \\
r\end{array}$} & & & & $\begin{array}{l}\text { Grey } \\
\text { Relational } \\
\text { Coefficien } \\
\text { (GRC) }\end{array}$ \\
\cline { 2 - 5 } & & Keausa & Kekasara & Keausa \\
& $\mathrm{n}$ & $\mathrm{n}$ & Kekasaran \\
\hline 1 & 0,000 & 0,388 & 1,000 & 0,563 \\
\hline 2 & 0,045 & 0,393 & 0,918 & 0,560 \\
\hline 3 & 0,841 & 0,757 & 0,373 & 0,398 \\
\hline 4 & 1,000 & 0,775 & 0,333 & 0,392 \\
\hline 5 & 0,465 & 0,000 & 0,518 & 1,000 \\
\hline 6 & 0,532 & 0,550 & 0,485 & 0,476 \\
\hline 7 & 0,899 & 0,226 & 0,357 & 0,689 \\
\hline 8 & 0,626 & 1,000 & 0,444 & 0,333 \\
\hline
\end{tabular}

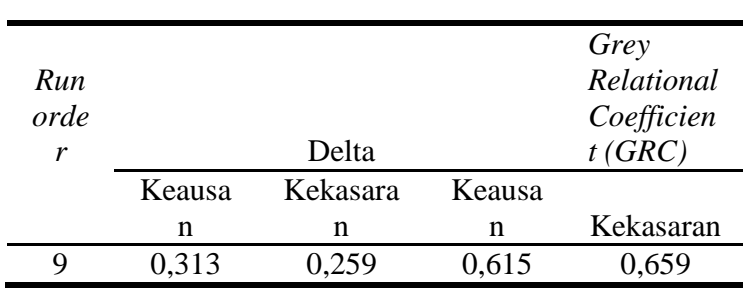

Pembobotan nilai GRC dilakukan dengan Principal Component Analysis memakai bantuan software perhitungan. Nilai principal component yang didapat adalah :

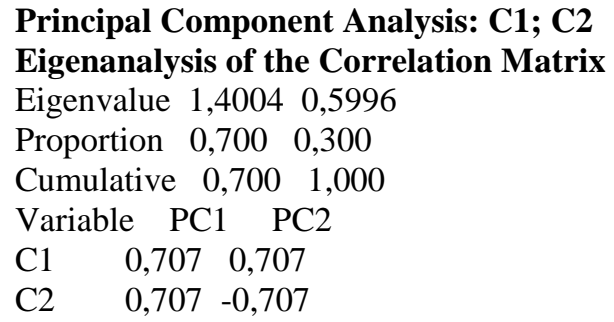

Berdasarkan hasil tersebut diperoleh data bahwa eigenvalue untuk Principal Component (PC) 1 adalah 1,4004 dan untuk Principal Component (PC) 2 adalah 0,5996. Menurut dasar teori yang disebutkan di Bab 2. 9, bahwa nilai PC utama yang dipakai untuk pembobotan dipilih nilai eigenvalue yang lebih besar dari satu (>1). Nilai eigen yang mendekati nol dianggap tidak memberikan pengaruh yang penting. Jadi diambil proporsi PC1 yang terbesar yaitu sebesar 1,4004 atau dapat menjelaskan sebesar $70 \%$ dari total varian. Nilai dari komponen eigen vector PC1 yang akan dipakai sebagai pembobotan. Hasil pembobotan dapat dilihat pada Tabel 10 .

Tabel 10. Pembobotan Principal Component

\begin{tabular}{lcc}
\hline Faktor & PC 1 & Bobot \\
\cline { 3 - 3 } & & PC1 Kuadrat $(\beta)$ \\
\hline Keausan & 0,707 & 0,500 \\
\hline Kekasaran & 0,707 & 0,500 \\
\hline
\end{tabular}

Sedangkan hasil perhitungan nilai Grey Relational Grade (GRG) dapat dilihat pada Tabel 11. 
Tabel 11. GRG

\begin{tabular}{ccc} 
Run order & GRG & Rank \\
\hline 1 & 0,781 & 1 \\
\hline 2 & 0,739 & 3 \\
\hline 3 & 0,373 & 9 \\
\hline 4 & 0,382 & 7 \\
\hline 5 & 0,746 & 2 \\
\hline 6 & 0,467 & 6 \\
\hline 7 & 0,511 & 5 \\
\hline 8 & 0,376 & 8 \\
\hline 9 & 0,624 & 4 \\
\hline
\end{tabular}

Dari Tabel 11 dapat diketahui nilai GRG terbesar ada di run order pertama, sehingga initial parameter ada pada kombinasi faktor A1 B1 C1 D1. Initial parameter tersebut belum menunjukkan nilai optimasi sesungguhnya. Selanjutnya dapat dicari nilai rata-rata GRG untuk menentukan kondisi optimal tiap faktor.

Hasil perhitungan nilai rata-rata GRG dapat dilihat pada Tabel 12 berikut:

Tabel 12. Nilai rata-rata GRG tiap faktor

\begin{tabular}{lcccc}
\hline & \multicolumn{4}{c}{ Faktor } \\
\cline { 2 - 5 } Level & $\mathrm{A}$ & $\mathrm{B}$ & $\mathrm{C}$ & $\mathrm{D}$ \\
\hline level 1 & $\mathbf{0 , 6 3 5 1}$ & 0,5557 & 0,5500 & $\mathbf{0 , 7 2 6}$ \\
\hline level 2 & 0,5339 & $\mathbf{0 , 6 2 8 6}$ & $\mathbf{0 , 5 7 9 3}$ & 0,581 \\
\hline level 3 & 0,5161 & 0,5007 & 0,5557 & 0,379 \\
\hline Max & 0,6351 & 0,6286 & 0,5793 & 0,726 \\
\hline Min & 0,5161 & 0,5007 & 0,5500 & 0,379 \\
\hline Diff & 0,1190 & 0,1279 & 0,0292 & 0,347 \\
\hline Rank & 3 & 2 & 4 & 1 \\
\hline
\end{tabular}

Dari Tabel 12 dapat diketahui nilai optimal dari semua respon dapat dicapai jika faktor percobaan disetting pada A1 B2 C2 D1. Setelah nilai GRG dan nilai optimal dari faktor gabungan didapatkan, dilakukan ANOVA untuk mengetahui signifikansi atau pengaruh paling besar dari faktor-faktor tersebut. Dengan bantuan software Minitab dapat dilakukan penghitungan ANOVA untuk semua nilai GRG tersebut.

Untuk itu akan dilakukan perhitungan ANOVA dengan menggunakan stepwise-forward selection. Dari hasil ANOVA diatas didapatkan bahwa faktor kecepatan makan menjadi satu-satunya faktor paling berpengaruh terhadap GRG dengan $\mathrm{F}$ hitung sebesar 10.73 dan persen kontribusi sebesar 78,15\%. Sedangkan F tabel $=\mathrm{F}(0,05 ; 3,6)=4,76$, maka $\mathrm{F}$ hitung kecepatan makan lebih besar dari $\mathrm{F}$ tabelnya.

Selanjutnya dilakukan tes konfirmasi memakai kombinasi faktor A1 B2 C2 D1 untuk membandingkan hasilnya dengan initial maupun prediksi. Confirmation test dilakukan dengan tiga kali replikasi. Hasil confirmation test dapat dilihat pada Tabel 13 berikut:

Tabel 13. Hasil Confirmation Test

\begin{tabular}{lrrrr}
\hline \multirow{2}{*}{ Respon } & \multicolumn{3}{c}{ Replikasi } & $\begin{array}{c}\text { Rata- } \\
\text { rata }\end{array}$ \\
\cline { 2 - 4 } $\begin{array}{l}\text { Keausan } \\
(\mathrm{mm})\end{array}$ & 0.088 & 0.04 & 0.049 & 0.059 \\
\hline $\begin{array}{l}\text { Kekasaran } \\
(\mu \mathrm{m})\end{array}$ & 0.371 & 0.352 & 0.369 & 0.364 \\
\hline
\end{tabular}

Kemudian dicari kembali nilai GRG hasil confirmation test tersebut. Hasil dari nilai initial, prediksi maupun confirmation dapat dilihat pada Tabel 14 berikut:

Tabel 14. Faktor optimal saat initial dan saat confirmation test

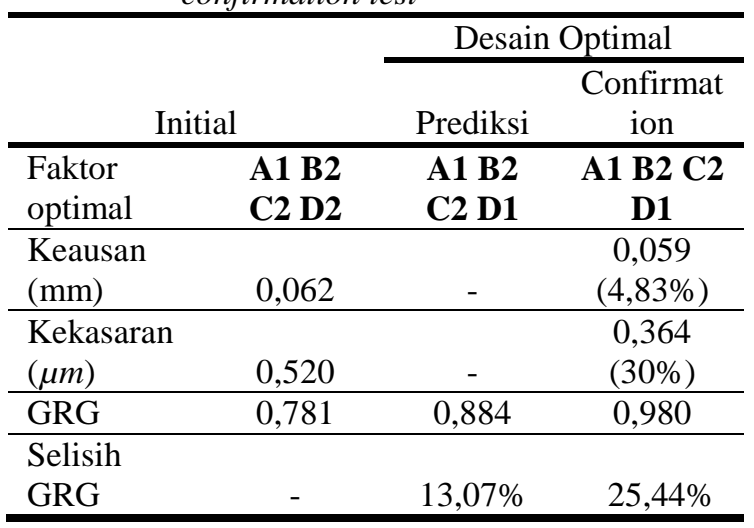

Hasil dari confirmation test menunjukkan adanya peningkatan nilai GRG maupun respon yang memperkuat bahwa prediksi kombinasi yang optimal dari empat faktor sudah benar. Nilai keausan dan nilai kekasaran hasil confirmation test lebih kecil dari nilai awal. Nilai keausan menjadi lebih kecil sebesar 4,83\% dari nilai initial. Nilai kekasaran permukaan menjadi lebih kecil sebesar 30\% dari nilai initial. 
Sedangkan GRG meningkat 25,44\% dari GRG initial. Sedangkan GRG prediksi meningkat 13,07\% dari GRG initial. Hal ini mengkonfirmasi bahwa perhitungan nilai kombinasi dari empat faktor yang optimal untuk menghasilkan keausan pahat optimal sekaligus juga kekasaran benda kerja yang optimal sudah benar.

Dengan Metode Taguchi didapatkan kecepatan makan dan kecepatan spindle berpengaruh signifikan terhadap masingmasing faktor (keausan maupun kekasaran permukaan). Tetapi saat digabungkan menjadi respon tunggal GRG dengan Metode Grey Relational Analysis faktor yang signifikan tinggal menjadi faktor kecepatan makan. Faktor kecepatan makan sejak dari Metode Taguchi sudah menunjukkan persen kontribusi yang dominan, yaitu sebesar $46,41 \%$ untuk keausan pahat dan 79,02\% untuk kekasaran permukaan dan kembali berkontribusi dominan sebesar 78,15\% untuk GRG.

Nilai optimal kecepatan makan hasil Metode Taguchi berada pada level tertinggi yaitu $220 \mathrm{~mm} / \mathrm{menit}$. Tetapi nilai optimal kecepatan makan hasil GRA berada di level terendah yaitu $75 \mathrm{~mm} / m e n i t$. Hal ini menunjukkan fenomena seakan terjadi "kompromi "dari faktor-faktor tersebut (sesuai dengan persentase kontribusi masing-masing) untuk mencapai nilai optimal respon tunggal yang mencerminkan nilai optimal bagi keausan pahat maupun kekasaran permukaan benda kerja. Nilai optimal bagi keausan pahat maupun kekasaran permukaan berarti nilai terkecil yang mampu dicapai, dalam hal ini sebesar 0,059 mm untuk keausan pahat dan 0,364 $\mu m$ untuk kekasaran permukaan benda kerja.

Kapasitas panas spesifik Magnesium yang tinggi dan konduktivitas termalnya yang baik menyebabkan panas dengan cepat dibuang selama pemesinan Magnesium. Kekasaran permukaan akhir pada permesinan Magnesium tidak dipengaruhi oleh kecepatan potong tetapi dipengaruhi oleh kecepatan makan. Kecepatan makan halus diperlukan untuk penyelesaian akhir, untuk menghindari panas berlebih.
Penyebab lain dari didapatkan nilai terkecil dari kecepatan pemakanan yang menjadi faktor optimal adalah waktu pemotongan yang singkat dan ada saat pahat berada di luar area potong. Ditambah lagi pahat yang dipakai berjenis 2 flute, sehingga bidang gesek lebih sedikit dan pembuangan panas lebih banyak. Laju keausan menjadi belum signifikan sehingga berdampak pula kepada kekasaran permukaan yang kecil.

Penggunaan pahat end mill 2 flute untuk pengerjaaan cepat, dapat memperlambat keausan pahat. Setting kecepatan makan di nilai rendah pada proses milling jarak pendek dapat menghindari chipping sehingga memperlambat aus tool. Perlu diperhatikan bahwa penurunan kecepatan makan yang terlalu tajam dalam sekali proses milling berpotensi membakar bagian pahat sehingga memperbesar aus.

Yaser and Shunmuresh [14] melakukan penelitian nilai optimal parameter mesin milling tetapi menggunakan benda kerja Fibre Reinforced Polymer. Metode olah data yang dipakai adalah GRA. Hasil penelitian tersebut menyebutkan bahwa untuk memperoleh kekasaran permukaan terkecil dipakai kombinasi kecepatan potong tinggi dengan kecepatan makan rendah.

Penelitian yang menyatakan kekasaran permukaan dipengaruhi signifikan oleh kecepatan makan dilakukan oleh Kanchana, et. al [15] yang meneliti multirespon pada milling berupa gaya potong, temperatur dan kekasaran permukaan dengan GRA. Pahat yang dipakai TiAlN coated carbide insert dan benda kerja yang dipakai custom 465 steel. Hasilnya menyatakan bahwa kecepatan makan merupakan faktor paling berpengaruh, sebesar $42,95 \%$ terhadap respon.

Penelitian Thamizhmanni, et. al [16] terhadap pemesinan turning untuk Titanium dan Innconel menggunakan CBN cutting tool menemukan hasil bahwa diantara tiga faktor (kecepatan pemakanan, kecepatan spindle dan kedalaman makan) yang diamati ternyata kecepatan makan berpengaruh 
signifikan untuk nilai optimal keausan pahat maupun kekasaran benda kerja.

Penelitian Hebbar, et. al [17] yang memakai mesin milling dan benda kerja Magnesium AZ 31 serta pahat single uncoated carbide insert dengan memakai tiga faktor (kecepatan potong, kecepatan makan dan kedalaman makan) menghasilkan kesimpulan bahwa kekasaran permukan optimal (nilai minimum) didapatkan dari kombinasi kecepatan makan terendah, kecepatan potong tertinggi dan kedalaman makan tertinggi.

Penelitian Kumar, et. al [18] terhadap pemesinan milling untuk AISI 1005 dengan TiN coated tool juga menemukan hasil bahwa diantara tiga faktor (kecepatan pemakanan, kecepatan spindle dan kedalaman makan) yang diamati ternyata kecepatan makan berpengaruh signifikan untuk nilai optimal keausan pahat maupun kekasaran benda kerja.

Penyebab lain dari keausan pahat yang cepat dan besarnya kekasaran permukaan pada pemesinan milling adalah adanya chatter. Chatter didefinisikan sebagai getaran yang masuk kedalam kondisi tidak stabil. Chatter dapat dihindari dengan memilih pahat dengan jumlah flute sedikit dan menurunkan kecepatan makan. Benda kerja Magnesium mempunyai daya tahan terhadap chatter yang lebih baik dibanding benda kerja kerja dengan bahan Stailess Steel ataupun Nickel Alloy [19]. Dalam pengujian yang dilakukan penulis, dipakai pahat dengan 2 flute dan diperoleh faktor signifikan yang berpengaruh terhadap gabungan respon adalah kecepatan makan dengan level terkecil. Hal ini dapat menyebabkan chatter tidak terjadi. Tetapi karena chatter tidak menjadi respon yang diamati, maka chatter tidak teridentifikasi dalam pengujian ini.

Jadi, hasil dari penelitian ini, mengindikasikan bahwa faktor yang berpengaruh signifikan terhadap masingmasing respon pada Metode Taguchi akan menjadi faktor berpengaruh juga untuk multirespon (GRA) tetapi dengan level yang tidak selalu sama

\section{Kesimpulan}

Dengan Metode Taguchi didapatkan bahwa semua faktor pemesinan yang diamati (diameter pahat, kedalaman makan, kecepatan spindle dan kecepatan makan) berpengaruh signifikan tehadap keausan pahat dengan kontribusi terbesar adalah faktor kecepatan makan sebesar 46,41\%. Sedangkan faktor kecepatan spindle dan kecepatan makan berpengaruh signifikan terhadap kekasaran permukaan benda kerja dengan kontribusi terbesar adalah faktor kecepatan makan sebesar 79,02\%.

Dengan Metode Grey Relational Analysis didapatkan kombinasi optimal dari faktor percobaan adalah A1 B2 C2 D1 (diameter pahat $6 \mathrm{~mm}$, kedalaman makan $1,5 \mathrm{~mm}$, kecepatan spindle $1280 \mathrm{rpm}$ dan kecepatan pemakanan $75 \mathrm{~mm} / \mathrm{menit}$ ), faktor signifikan adalah kecepatan makan dengan kontribusi $78,15 \%$. Nilai respon optimal (terkecil) untuk keausan sebesar 0,059 mm serta kekasaran permukaan sebesar 0,364 $\mu m$. Hasil Grey Relational Grade (GRG) dari faktor optimal A1 B2 C2 D1 adalah 0,980 . Nilai itu meningkat sebesar 25,44\% dari nilai GRG awal.

\section{Referensi}

[1] P. Zgórniak and A. Grdulska, "Investigation of temperature distribution during milling process of AZ91HP magnesium alloys," Mech. Mech. Eng., vol. 16, no. 1, pp. 33-40, 2012.

[2] R. Pereira, "Mechanical behaviour of AZ31B Magnesium alloy subjected to in-plane biaxial fatigue experimental methods," no. May, pp. 1-10, 2016.

[3] S. R. Sulistiyanti, et. al, "Characterization of Cutting Temperature and Ignition Phenomena of Magnesium Chip Using Infrared Imaging," Adv. Mater. Res., vol. 588-589, pp. 1744-1747, 2012.

[4] T. Childs, et. al, "Metal machiningtheory and applications," Arnold, London, p. 416, 2000.

[5] H. A.-G. El-Hofy, Fundamentals of 
machining processes: conventional and nonconventional processes. 2013.

[6] E. Ersvik, "Milling in hardened steel - a study of tool wear in conventionaland dynamic milling," no. June, 2015.

[7] K. Shi, J. Ren, et. al, "Tool wear behaviors and its effect on machinability in dry high-speed milling of magnesium alloy," Int. J. Adv. Manuf. Technol., vol. 90, no. 912, pp. 3265-3273, 2017.

[8] T. Dominic, "Modeling of tool wear and tool fracture in micromilling," no. December, 2011.

[9] S. Muralidharan, et. al, "A study on machinability characteristic in end milling of magnesium composite," Int. J. Mech. Eng. Technol., vol. 8, no. 6, pp. 455-462, 2017.

[10] P. M. Gopal and K. Soorya Prakash, "Minimization of cutting force, temperature and surface roughness through GRA, TOPSIS and Taguchi techniques in end milling of $\mathrm{Mg}$ hybrid MMC," Meas. J. Int. Meas. Confed., vol. 116, pp. 178-192, 2018.

[11] Taguchi, Genichi, Subir Chowdhury and Yuin Wu. 2005. Taguchi's Quality Engineering Handbook. Jhon Wiley \& Sons , Inc

[12] N. Tamiloli, et. al, "A grey-fuzzy modeling for evaluating surface roughness and material removal rate of coated end milling insert," Meas. J. Int. Meas. Confed., vol. 84, pp. 6882, 2016.

[13] K. Aslantas, et. al, "Optimization of process parameters for micro milling of Ti-6Al-4V alloy using Taguchibased gray relational analysis," Meas. J. Int. Meas. Confed., vol. 128, pp. 419-427, 2018.

[14] Yaser, E K and K Shunmugesh. 2018. Multi-Objective Optimization of Milling Process Parameters in Glass Fibre Reinforced Polymer Via Grey Relational Analysis And Desirability Function. Materials Today:
Proceedings 11 (2019) 1015-1023

[15] J. Kanchana, Prasath V, Krishnaraj V and Geetha Priyadharshini B. 2018. Multi Response Optimization Of Process Parameters Using Grey Relational Analysis For Milling Of Hardened Custom 465 Steel.Procedia Manufacturing Journal. 30 : 451-458

[16] Thamizhmanii, S, Dr.C.Yuvaraj, JS Senthilkumar, Arun I and, Sulaiman. 2019. Effect of Feed Rate on Difficult to Cut Metal on surface Roughness and Tool Wear Using Surface Treated and Untreat Tools.Procedia Manufacturing 30 (2019): 216-223

[17] Hebbar, Gautama, Grynal D’Mello, and Srinivasa Pai P. 2018. Surface Roughness Optimization in Machining of Biodegradable Magnesium Alloys. Materials Today: Proceedings

[18] Kumar, Kumar, I. Saravanan and Lokeswar 2019. Optimization of Surface Roughness and Material Removal Rate in Milling of AISI 1005 Carbon Steel Using Taguchi Approach. Materials Today: Proceedings

[19] Kalpakjian, S and Schmid, SR. 2002. Manufacturing Engineering and Technology. International edition, Prentice Hall. New Yersey. 